\title{
SET-ASIDES AND CERTIFICATES OF COMPETENCY- POSITIVE PROGRAMS FOR SMALL BUSINESS IN GOVERNMENT PROCUREMENT
}

\author{
FrEdRIC T. Suss*
}

\section{INTRODUCTION}

Small business, particularly its economic health and opportunity for growth and expansion, traditionally has been the subject of special concern to the President and the Congress. Aware of the impact of government procurement on industry, both have devoted much effort toward increasing the participation of small business concerns in government procurement.

Indicative of the presidential interest is the creation of a White House Committee on Small Business consisting of representatives of the major federal departments and agencies and the issuance of directives to procurement officials to increase the government contracts awarded to small firms. ${ }^{1}$ The congressional interest is manifested by the establishment of special committees on small business by both the Senate and the House of Representatives and by enactment of the Small Business Act, section 2(a) of which provides: ${ }^{2}$

... It is the declared policy of the Congress that the Government should aid, counsel, assist, and protect, insofar as is possible, the interests of small-business concerns in order to preserve free competitive enterprise, to insure that a fair proportion of the total purchases and contracts or subcontracts for property and services for the Government . . . be placed with small-business enterprises, to insure that a fair proportion of the total sales of Government property be made to such enterprises ...

Notwithstanding these good intentions and explicit directives, small business has continued to fall behind in its participation in America's accelerated defense and space effort. Between $I 954$ and $I 963$ this share declined from 25.3 per cent to 15.8 per cent of the military awards to business firms for work to be performed in the United States. By way of comparison, just three large concerns (Lockheed Aircraft Company, Boeing Company, and North American Aviation, Inc.) received 15.2 per cent of the I 963 military procurement expenditures.

The procurement history of the National Aeronautics and Space Administration

* General Counsel, Small Business Administration.

${ }^{1}$ For example, President Kennedy, on March 15, 196r, called for a 10\% increase in awards to small firms. N.Y. Times, March I6, 196r, p. 20, col. 2.

${ }^{2} 72$ Stat. 384 (1958), 15 U.S.C. $\$ 631$ (1958). The Small Business Act was originally enacted as title II of the Act of July 30, I953 (67 Stat. 233), and was designated the "Small Business Act of I953." The 1953 statute, which was to expire in 1955, was extended and amended by Acts of June 30, 1955 (69) Stat. 255), Aug. 9, r955 (69 Stat. 547), Fcb. 2, 1956 (70 Stat. 10), and Feb. Ir, 1957 (7r Stat. 1), Aug. 3, 1957 (71 Stat. 341), Feb. 22, I958 (72 Stat. 27), and July 18 , I958 (72 Stat. 384). The last cited statute made title II of the Act of July 30, 1953, a separate act with the short title "The Small Business Act." It also made the legislation permanent. 
Department of Defense Awards to Business Firms in the United States

Per Cent of Total Awarded to Small Business

$\begin{array}{rrr}\text { Fiscal Year } & 1954 & 25.3 \% \\ & 1955 & 21.5 \% \\ 1956 & 19.6 \% \\ 1957 & 19.8 \% \\ 1958 & 17.1 \% \\ 1959 & 16.6 \% \\ 1960 & 16.1 \% \\ 1961 & 15.9 \% \\ 1962 & 17.7 \% \\ 1963 & 15.8 \%\end{array}$

(NASA) also reflects a drastic reduction in contract awards to small concerns. Between 1959, when NASA was created, and June $30, x 963$, the percentage fell from I8.2 per cent to 8.4 per cent.

Of even greater significance is the fact that the small business share of military procurements is limited largely to hardware, simple metal fabrication and the like, with contracts for research and development going to their large competitors. In fiscal year 1963 , small concerns received only 3.5 per cent of the military research and development contracts, down from 5.7 per cent in 1956 . This minimal share may well portend a continuation in the decline of their share of military production awards.

If one were to generalize as to the cause of this precarious position of small business, he would have to conclude that the adverse factors fall into two broad categories. The first results from the problems and perplexities confronting all who seek to do business with the government. For the government contractor, be he large or small, experienced or novice, it is a continuing struggle with complex, verbose, and, at times, conflicting regulations. He must deal with the ever-present threat of a termination by the government for its own convenience and without payment of damages, as such; the government's unilateral right to make changes in the work without immediate adjustment of the contract price; the power of the contracting officer unilaterally to resolve disputed questions of fact subject only to an appeal to the head of the procuring agency; demands for patent, proprietary, cost and price data, which often seem arbitrary and high-handed. In addition, his profits are curtailed and even renegotiated, and his contract administration is overburdened because of technical requirements. These are but a few of the reasons why many firms, regardless of size, have preferred to withdraw from government procurement. For many small concerns, these difficulties are accentuated because their limited management resources preclude them from being fully aware of their rights or cause them to hesitate to enforce these rights.

The second category includes disabilities peculiar to small business concerns. 
The increasing need for complex, sophisticated weapons systems, ${ }^{3}$ the emphasis on short-run, high cost items, a product mix in which skilled engineering rather than factory labor predominates and the use of negotiation rather than advertising as the procurement tool for awarding contracts, have removed a large portion of the military and space procurement programs from the small business potential. To this must be added the continuing reluctance of some government contracting officers to do business with small business whenever they can award the contract to a larger and better known competitor. ${ }^{4}$

Efforts are being made to eliminate the difficulties applicable to contractors generally. However, the special problems of small concerns require special treatment.

If small business is to be preserved as a vital force in our military and space procurement, the factors of reduced potential and contracting personnel reluctance must be counteracted. Two programs aimed in this direction are the small business set-aside program and the certificate of competency program. The former provides an area of competition exclusive to small concerns; the latter is to neutralize the contracting officer's almost unlimited power to refuse to do business with a concern which he does not believe can perform. Since both these programs are vital to the small businessman and are replete with legal implications, it is well for the legal adviser to small concerns to be fully familiar with the way they operate and the rules applicable to them. The purpose of this article is to examine these two procurement programs. But no small business program could adequately be covered without a preliminary discussion of the rules for determining which concerns qualify as small business for procurement.

\section{Defining a Small Business Concern for Procurement ${ }^{5}$}

Section 8(b) (6) of the Small Business Act ${ }^{b}$ authorizes the Small Business Administration (SBA) to determine within any industry which business enterprises are small business concerns. This determination is conclusive on government officials having procurement powers. The act also provides that:

For the purposes of this Act, a small-business concern shall be deemed to be one which is independently owned and operated and which is not dominant in its field of operation.

"A weapon system, as contrasted with a weapon, is simply an entity consisting of an instrument of combat, such as an aircraft or missile, together with all related equipment and supporting facilitics required to bring the instrument upon its target or to the place where it performs the function for which it was built. Dep't of Defense Procurement Presentation to the Procurement Sun. committee of the Senate Committee on Armed Services 28 (1960).

'See H.R. Rep. No. 2718, 85th Cong., 2d Sess. 79 (1959); S. Rep. No. 1170, 85th Cong., 2d Sess. 27 (1958); Report of the Attorney Generai, Pursuant to Section 708(e) of the Defense Production ACT OF I950, As AMENDED 23 (1956).

There are three separate definitions of a small business concern, to wit, for government procurement, for financial assistance from Small Business Administration (SBA) and for assistance from Small Business Investment Companies. For a discussion of the third definition, see Davidson, What Is a "Small Business Concern" Under the Small Business Investment Act of 1958?, 20 FED. B. J. 332 (1960).

${ }^{8} 72$ Stat. 390, I5 U.S.C. $\$ 637$ (b)(6) (1958). 
In addition to the foregoing criteria the Administrator [of the Small Business Administration] in making a detailed definition, may use these criteria, among others: Number of employees and dollar volume of business. Where the number of employees is used as one of the criteria in making such definition for any of the purposes of this Act, the maximum number of employees which a small-business concern may have under the definition shall vary from industry to industry to the extent necessary to reflect differing characteristics of such industries and to take proper account of other relevant factors. ${ }^{7}$

Pursuant to this authority, SBA has defined a small business concern for the purpose of government procurement as one which, including its affiliates, is independently owned and operated, is not dominant in the field of operations in which it is bidding, and can qualify under the following additional criteria: ${ }^{8}$

(a) average annual receipts for its preceding three fiscal years of not more than (I) $\$ 7 / 2$ million if the procurement is for construction, alteration, or repair of real property, including roads; ${ }^{9}$

(2) $\$ 5$ million if the procurement is for dredging; ${ }^{10}$

(3) \$I million if the procurement is for services not elsewhere defined; ${ }^{11}$

(b) annual receipts for its preceding fiscal year of not more than $\$ 3$ million if the procurement is for local or long distance trucking, warehousing, packing and crating, and/or freight forwarding services; ${ }^{\mathbf{1 2}}$

(c) not more than 1,000 employees if the procurement is for air transportation, and not more than 500 employees if it is for other types of passenger or freight transportation services; ${ }^{13}$

(d) not more than 500,750 , or 1,000 employees if the procurement is for a manufactured product or for research and/or development which requires the delivery of a manufactured product other than canned and preserved food, petroleum (excepting lubricants and miscellaneous petroleum products), depending on how the product is classified in the four digit Standard Industrial Classification issued by the Bureau of the Budget. The criteria for food canning and preserving procurements are a maximum of 500 persons, exclusive of agricultural labor, while the criteria for petroleum procurements (excepting lubricants, and so forth) are a maximum of $\mathrm{r}, 000$ employees and a crude oil refinery capacity of 30,000 barrels per day. ${ }^{14}$ If the concern is a dealer, distributor or other non-manufacturer, its number of employees cannot exceed 500 and it must furnish the product of a small concern. ${ }^{15}$ If the procurement is for research and/or development, but does not require the

${ }^{7} 72$ Stat. 384 , 55 U.S.C. $\$ 632$ (1958).

${ }^{\circ}$ SBA Rules and Regulations, §12I.3-8, 29 Fed. Reg. 89 ( $x_{964) .}$

Id. $\$$ I2I.3-8(a)(I).

${ }^{10} \mathrm{Id}$. $\$ \mathrm{r} 2 \mathrm{r} .3-8(\mathrm{a})(2)$.

${ }^{11}$ Id. $\$ 121.3-8(\mathrm{c})$.

${ }^{12}$ Id. $\$$ I2I.3-8(f) (3).

${ }^{13} \mathrm{Id}$. $\S \mathrm{I2T} \cdot 3-8(\mathrm{f})(\mathrm{I})$ and (2).

${ }^{14} I d$. $\S \mathrm{I} 21.3-8(\mathrm{~b})$ and (d)(I). For a definition of "crude-oil capacity," sec $i d$. $\S$ I2I.302(c).

${ }^{20}$ Id. $\$ 121.3-8(\mathrm{c})$. 
delivery to the government of a manufactured product, or is for testing, the criterion is a maximum of 500 employees. ${ }^{16}$

The term "number of employees" means the average employment of a concern, including the employees of its affliates, based on the number of persons employed on a full-time, part-time, temporary, or other basis during the pay period ending nearest the last day of the third month in each calender quarter for the preceding four quarters. ${ }^{17}$

Industry size standards for procurement reflected a deliberate effort by SBA to meet criticism that it was not carrying out the full intent of section three of the Small Business Act. ${ }^{18}$ Prior to July I, 1963 , the size standard was, with limited exceptions, the rule originally conceived by the military agencies before SBA's creation, to wit: not more than 500 employees. SBA deviated from this 500 employee rule in those industries or fields of operation where there was a high concentration of output in a few companies with over 500 employees and a limited number of companies with 500 or fewer employees. In this area, SBA, upon request would issue a Small Business Certificate to a firm having more than 500 but less than r,000 employees, the certificate declaring the concern to be small business for the products or services specified therein.

The use of these Small Business Certificates created numerous problems. Since there were no definite standards for granting these certificates for most industries, a concern could not bid on small business procurement until its application for a certificate had been processed and approved. This unfortunately could and did prevent firms from bidding on procurements for which they subsequently were determined to be eligible. In addition, many firms eligible to apply for certificates were unaware of them even though SBA had announced their availability in the Federal Register.

Because of these difficulties, SBA abolished as of July $x, 1963$, the certificate program and adopted a variable standard based upon industry classifications as defined in the Standard Industrial Classification Manual. In formulating employee standards for the various industrial classifications SBA considered:

I. concentration of output;

2. coverage ratio;

3. primary product specification ratio;

4. absolute number of concerns;

5. size of industry (dollar volume);

6. employment size of industry leaders; and

7. government procurement history.

${ }^{10} 1 d$. $\$$ r2I.3-8(d)(2).

${ }^{17} I d$. \$ $121 \cdot 3-2(\mathrm{q})$.

${ }^{18}$ H.R. REP. No. 2513, 82d Cong., 2d Sess. 4, 5 (1952); H.R. REP. No. 1045, 84th Cong., 1st Sess. 7 (1955); H.R. Rep. No. 1350, 84th Cong., Ist Sess. 8, 9 (1955); H.R. Rep. No. 2964, 84th Cong., 2d Sess. 9, xo (1956); H.R. REP. No. 2135, 85th Cong., 2d Sess. 4 (1958); H.R. Rep. No. 2715, 85th Cong., 2d Sess. 6, 7 (1959); and H.R. Rep. No. 2235, 86th Cong., 2d Sess. 82, 83 (1960). 
As may be expected, there has been some industry objection to the new standards. Nevertheless, experience since July $I$, Ig63, albeit limited, warrants the belief that the new approach will eliminate much of the previously existing uncertainty concerning the size of a business concern and will reflect more truly the realities of industrial relationships.

In determining size, SBA looks not only to the particular concern involved, but also to companies with which it is related or "affiliated." The criterion of affliation is control or power to control-that is, concerns are affiliated when either directly or indirectly one controls or has the power to control the other or when third parties control or have the power to control both. ${ }^{19}$ A person holding fifty per cent or more of a concern's voting stock is considered to have control or the power to control such concern without regard to whether he in fact exercises such control. When the holding is less than fifty per cent, but is large compared to other holdings, power to control likewise is deemed to exist. In appropriate instances, as little as thirteen per cent has been found sufficient to enable the owners to exercise control of concerns whose stock is publicly and widely owned. Persons having a community of interest and who act in concert are considered as a unit and their stock as a single block.

Common control may exist apart from stock ownership-as, for example, where two concerns have a common management. Common control clearly exists where a majority of the officers and directors of one concern also serve as the officers and directors of another. Common control also may exist when two concerns have a common principal officer; and it also may result from contractual relations, as through a franchise which enables the franchisor to take from the franchisee the rights to make its own business decisions. Joint ventures by their very nature result in affiliation for the performance of the joint venture project, but not for other projects in which the joint venturers have no common interest.

\section{II}

\section{Small Business Set-Asides}

The increasing complexity of the items bought by the government, the growth of the weapons system method of procurement, ${ }^{20}$ the greater use of negotiation with pre-selected firms, and similar factors all have contributed to limiting the areas in which small business concerns can compete. One of the principal methods of countering this decline in the "small business potential" is to limit to small firms those areas of procurement where they are competent and competitive in terms of quality and price.

The importance of the small business set-aside program is evident from the fact that from August $\mathrm{x}, \mathrm{x} 953$, through September $30^{\circ}, 19.63,177,000$ military procure ments were set aside. As a result, small concerns received contract awards valued

${ }^{10}$ SBA Rules and Regulations, $\$ 121.3-2(a), 29$ Fed. Reg. 87 (r964).

${ }^{20}$ See note 3 supra. 
at approximately $\$ 7.8$ billion. During fiscal year $\mathrm{rg}^{6} 6$, a total of 33,239 set-asides of military procurements were made and resulted in awards aggregating more than $\$ 1,546,580,000$ or almost thirty-six per cent of the approximately $\$ 4,300,000,000$ in military contracts awarded to small business concerns during the same period. The latter amount constituted 15.8 per cent of the total military procurement awards to all business firms for work to be performed in the United States for fiscal year $1963{ }^{21}$

Small business set-asides are authorized by section fifteen of the Small Business Act, which provides, in part:

... small-business concerns ... shall receive any award or contract or any part thereof, and be awarded any contract for the sale of Government property, as to which it is determined by the [Small Business] Administration and the contracting procurement or disposal agency ( $I$ ) to be in the interest of maintaining or mobilizing the Nation's full productive capacity, (2) to be in the interest of war or national defense programs, (3) to be in the interest of assuring that a fair proportion of the total purchases and contracts for property and services for the Government are placed with small-business concerns, or (4) to be in the interest of assuring that a fair proportion of the total sales of Government property be made to small-business concerns ....22

The statute requires the mutual effort of the procuring officials and SBA. In order to insure prompt and accurate knowledge of procurements suitable for small business set-asides, SBA representatives are assigned to the major federal procurement offices to review all proposed procurements. They recommend for set aside procurements or classes of procurements meeting one or more of the above-quoted statutory criteria if there are sufficient small business concerns capable of performing at reasonable prices. ${ }^{23}$ Ordinarily the entire procurement is recommended for setaside, in which event it is termed a roo per cent or total set-aside. ${ }^{24}$ Only a portion of the procurement is recommended for set-aside (termed a partial set-aside) if it is determined that:

a. a total set-aside is not appropriate;

b. the procurement can be separated into two or more economic production runs or reasonable lots; and

c. one or more small business concerns have the technical competency and productive capacity to perform a portion of the procurement at a reasonable price. ${ }^{25}$

The final decision to make a set-aside, either total or partial, is not SBA's since section fifteen of the Small Business Act also provides that "whenever the [Small Business] Administration and the contracting procurement agency fail to agree, the matter shall be submitted for determination to the Secretary or the head of the

\footnotetext{
${ }^{21}$ Dep't of Defense, Report, Mtutrary Prime Contract Awards and Subcontract Payments (1963); Smali Business Administration, Report, Joint Procurement Set-Aside Procram (1963).

${ }^{22} 72$ Stat. 395, 15 U.S.C. $\$ 644$ (1958).

${ }^{23}$ SBA Rules and Regulations, \$ I27.15-2(a), 28 Fed. Reg. 13546 (1963).

${ }^{24} 1 d$. \$127.15-2(a)(2).

${ }^{25} 1 d . \$ 127.15^{-2}(\mathrm{a})(4)$.
} 
appropriate department or agency by the Administrator [of the Small Business Administration]."26

The discretion of the contracting agency has been respected by the Comptroller General. ${ }^{27}$ Thus, in Decision B-150887, dated April 25, I963, he sustained the refusal of a contracting agency to make a set-side where the agency was of the opinion that the scope of the work was beyond the capability of small business concerns and that it was not reasonable to expect that bids offering reasonable prices would be received from a sufficient number of capable small concerns, even though it subsequently developed that small concerns submitted six of the thirteen bids received, and three of the five lowest prices were from small concerns.

This refusal to permit hindsight to govern applies only to decisions not to make set-asides. When a set-aside has been made, the disclosure by the bidding that the set-aside was improper (i.e., would result in unreasonable prices) is a ground for rejection of all bids, cancellation of the set-aside, and reletting on a different basis. ${ }^{28}$

The question of "unreasonable prices" is one that cannot be resolved by the application of a precise formula, particularly since too frequently there is no precise price that can be used as a criterion. In government procurement bid prices for non-commercial items tend to vary with each procurement depending on many factors-including the extent to which a concern is "hungry" for the award, its estimate of what competitors are likely to bid, or the nature of the changes it believes it may be directed to make. To this extent, it is not too unlike an auction where the bidders may try to outfox each other. Then, too, there are questions such as start-up costs which may or may not have been previously absorbed, production know-how, and the like. For these and other reasons the price a concern will bid can, and frequently does, vary from procurement to procurement.

Despite this lack of a precise formula an unexplained differential of ten per cent from the previous procurement has been held sufficient to warrant a finding of "unreasonable prices." A fortiori, withdrawal of the set-aside was held proper where the differential between the low bid of the small business concern and that of a large business concern was nineteen per cent $t^{30}$ and thirty-four per cent. ${ }^{31}$ On the other hand, where the low bid of a small business concern was $\$ I, 5$ IO as compared to $\$ \mathrm{r}, 500$ per unit bid by a large business concern and the bids submitted by all small business concerns were substantially lower than the prices paid on previous procure-

${ }^{20}$ See note 22 supra.

${ }^{27}$ Comp. Gen. Dec. No. B-15r419, June 25, 1963.

${ }^{20}$ Armed Services Procurement Regulation (ASPR) $\$ \mathrm{I}-706.3,32$ C.F.R. $\$$ I.706-3 (x96r), and Federal Procurement Regulations (FPR) I-I.706.3, 4I C.F.R. \$ I-I.706.3 (1963). ASPR is applicable to military procurement agencies while FPR regulates most civilian procurement agencies.

${ }^{30}$ Cf. Comp. Gen. Dec. No. B-132202, Aug. 30, 1957, 37 Decs. Comp. Gen. I47 (1957).

${ }^{30}$ Id. Dec. No. B-15174I, July 30, 1963.

${ }^{81}$ Id. Dec. No. I5019x, March 8, 1963. The Comptroller General also utilized the price bid on readvertising after cancellation of the initial set-aside to justify a finding that the bid price on the initial set-aside was unreasonable. Id. Dec. No. B-r 45376, Aug. II, 196r. See also id. Dec. No. B-I $5298 \mathrm{r}$, Jan. 22, 1964 , where the differential was $13 \%$. 
ments of similar services, the prices were held to be fair and reasonable and the protest of the large business bidder was denied. ${ }^{32}$

It has been suggested that the Comptroller General by comparing the bids of the small business concern to those of ineligible large business concerns has sanctioned the submission of "courtesy" bids of large business concerns-i.e., bids submitted by concerns that know they are ineligible to bid solely for the purpose of providing a basis for determining whether the bids of small firms are "unreasonable." This conclusion is without a sound legal basis, having only the dictum in Decision $\mathrm{B}-\mathrm{I} 45376^{33}$ in its support.

The policy of using "courtesy" bids for any purpose does not appear to be consistent with applicable statutory or regulatory requirements, as they require only that the award be made at "reasonable prices."34 Similarly, comparison with such bids is not consistent with government procurement concepts because they are not responsive and non-responsive bids are devoid of legal effect. ${ }^{35}$ Finally, "courtesy" bids should not be considered persuasive because the large concern, aware that its bid cannot be accepted, can deliberately bid low and, with impunity, achieve its aim of destroying the set-aside. The-most recent decision of the Comptroller General, B-I52I53, dated December 30, I963, has apparently recognized that the propriety of a set-aside cannot be adjudicated solely by comparing the bids of the small business concerns with those of large concerns. In this decision he stated,

${ }^{32}$ Id. Dec. No. B-139037, May 7, I959, 38 Decs. Comp. Gen. 744 (1959).

${ }^{83}$ Note 3 I stipra. The full text of the Comptroller General's decision on this point is "A 'courtesy" bid' would appear to be a factor proper for consideration." However, this statement is obiter dictum since the bid comparison utilized by the Comptroller General was between the price bid on the initial set-aside which was cancelled and the price bid on the readvertised invitation. In this decision, he also quoted from Dec. No. B-132202, supra note 29. That decision, however, only passed on whether an applicable regulation specifically limited the use of "courtesy" bids. It expressly refrained from passing on the propriety of using "courtesy" bids. "The provision does not specifically limit utilization of courtesy bids to future procurements only, although it affirmatively provides for such use. In this case, whether the Thorn bid was properly for consideration in determining to withdraw the set-aside is moot since there were sufficient other factors (the fact, contrary to what had been supposed, that Thorn was not a small business, and the difference between the low responsive bid and the price for the material in prior procurement plus adjustment for changes in the market) to reasonably support the withdrawal." Moreover, in that decision as in Dec. No. B-r5r74r, supra note 30, and Dec. No. B-15oigr, stupra note $3 \mathrm{r}$, the bids of the large concerns were not truly "courtesy" bids since the Comptroller General in cach instance expressly found that the concern acted in good faith and believed itself to be a small concern when it bid. Whether the bid of the low bidder (Central States Paper Company) considered in Dec. No. B-15298x, note 3I, supra, was a "courtesy" bid or whether it was submitted by a concern which believed itself as qualifying as a small business concern cannot be ascertained from the facts contained in the decision, although the Comptroller General did state that the contracting officer would not have made the set-aside if he had known Central States Paper Company was not a small business concern. In addition the comparison of the bids on the reprocurement was with that of a company other than Central States Paper Company and the justification for sustaining the withdrawal of the set-aside was the contracting officer's report that he agreed to the set-aside solely because he thought Central States Paper Company was a small concern. We may conclude from these facts that the Comptroller General did not view this decision as involving a "courtesy" bid.

84 ASPR x-706.5, 32 C.F.R. \$ 1.706-5 (Supp. 1963), and FPR-x-x.706.5, $4 x$ C.F.R. \$ x-1.706-5 (1963). See also Comp. Gen. Dec. No. B-152153, Dec. 30, 1963.

${ }^{35}$ Comp. Gen. Dec. No. 134074, Nov. 15, 37 Decs. Comp. Gen. 330 (1957); id. Dec. No. B-145184, June 12, 1961, 40 Decs. CoMp. GeN. 679 (I96I); see also Prestex, Inc. v. United States, Ct. Cl. Dec. No. 4I5-6I, July I2, I963. 
We know of no requirement, statutory or regulatory, which would make a total small business set-aside contingent upon a determination that costs to the Government would not be increased thereby. B-I45698, dated June I, I96r; B-I47333, dated November 21, 1962. ASPR 1-706.5 does not require a "testing of the market" but only requires that a reasonable expectation exists that sufficient small business concerns will submit bids to afford adequate price competition. Hence, the fact that lower bids may be expected from large business concerns is not a significant factor in determining whether a procurement should be set aside for small business participation only.

From the foregoing, it is apparent that neither I5 U.S.C. $\$ 644$ nor the procurement regulations impose any requirement that the prices offered under a total set-aside procurement be equal to, or better than, prices which might reasonably have been anticipated as a result of unrestricted competition.

There is one aspect of size determination peculiar to the small business set-aside program: When is the status of a bidder as a small business concern to be determined-at the time of bid opening or of award? One would think that the date should be that of bid opening since the acceptability of a bid is normally determined as of bid opening. However, the Comptroller General, relying on the phrase "shall receive any award" in section fifteen, has held that the determination is to be made as of the date of award. ${ }^{36}$ In Decision B-I43630, dated October 13, I960, the Comptroller General stated: "The date of award must of necessity fix and establish the rights and obligations of the parties to the contract, including the legal capacity of a bidder to receive an award which is restricted by statute to a certain class of bidders."

This rule was certain to engender problems, as it enables firms which are large when bids are opened to bid and if low to contrive to become small in order to receive the award. Thus, they would have the option, after all prices are known, to become eligible for award or to be declared non-responsive and have their bids rejected. The Comptroller General, alert to this, has grafted two exceptions on the rule that award date is controlling. The first is that where a large business concern submits a bid in which it certifies itself as a large business, and after bid opening but prior to award, becomes a small business concern, the bid is non-responsive on its face (not a bid of a small business concern) and is not entitled to consideration. ${ }^{37}$ The second exception involves bidders which in their bids certify themselves to be small business concerns, although they know or have reason to believe that their small business status is subject to question, and after opening of bids take whatever action is needed to become small. Such bidders, the Comptroller General has said, do not prudently utilize the self-certification procedure. The changes after bid opening would afford them a second chance and an undue advantage over the other bidders; therefore, they are not eligible for award..$^{38}$

${ }^{30}$ Comp. Gen. Dec. No. B-151448, July 22, 1963; id. Dec. No. B-143630, Oct. 13, 1960; id. Dec. No. B-r 49333, Aug. Io, I962, 42 Decs. CoMp. GEN. I08 (Ig62).

${ }_{87}$ Id. Dec. No. B-I 45236 , March 29, 1961, 40 DEcs. CoMp. GeN. 550 (196r), distinguishing Dec. No. B-143630, supra note 36 .

${ }^{8 B}$ Id. Dec. No. B-I $4462 \mathrm{I}$, Aug. I, I961, $4 \mathrm{I}$ Decs. CoMp. GEN. 47 (x96r), distinguishing Dec. No. B-143630, supra note 36 . 
While the bidder must be a small business concern when award is made to it, a change of its status to a large business subsequent to award will not invalidate the award. The Comptroller General has held that there is "no regulatory or statutory requirement that a small business bidder must retain its small business size subsequent to award or throughout contract performance to lend legality to the award which was proper when made."30

Generally, as noted above, the Comptroller General has ruled that an award can be made under a total small business set-aside only to a small business concern and awards to large concerns may be cancelled. ${ }^{40}$ However, after establishing this principle, the Comptroller General has nevertheless refused to apply it and to direct cancellation of contracts awarded to large concerns where ". . . it would be inequitable and serve no useful purpose . . ."; "... would be detrimental to the best interest of the Government";" 42 or "... would not be in the Government's best interest. ..."

These cases were all instances in which the government, as a party to the contract, considered the cancellation of the contract. The question whether the contractor may have the contract declared unenforceable because it was not a small business concern was considered by the United States Court of Claims in the recent case of Otis Steel Products Corporation $v$. The United States. ${ }^{44}$ In that case it appeared that the Otis Steel Products Corporation was a small business concern when it submitted its bid but was not such at the time award was made to it as its stock had been acquired by a large business concern. The Court of Claims held that the plaintiff was bound by the contract and said:

Plaintiff cannot be relieved of the obligation the contract imposed upon it by pleading that it was not a small business concern at the time the contract was awarded. The Small Business Act was passed for the benefit of small business concerns. The award of a contract to one representing itself to be a small business was a benefit conferred, not a penalty imposed. The award of a contract to one representing itself to be one of those entitled to the benefits of the Small Business Act cannot be set aside at the instance of one receiving the benefit, on the ground that it is not entitled to it. This is a ground available only to the one injured by the error; not to one who benefits by it.

'Id. Dec. No. B-144432, Aug. 21, x96I, 4I Decs. Comp. Gen. 124 (196r).

${ }^{10}$ Id. Dec. No. B-121145, Sept. 3, 1954, 34 Decs. Comp. Gen. I15 (1954).

${ }^{11}$ Id. Dec. No. B-146438, Oct. 16, I96r, 4 r Decs. Comp. Gen. 252 (196r).

12. Dec. No. 145948, Aug. 2, 196I.

${ }^{4}$ Id. Dec. No. B-152134, Oct. 24, 1963. Additionally, an interesting but not wholly answered question is whether the small concern that should have but did not receive the award has any rights, Prior to Heyer v. United States, I35 Ct. Cl. 63 (1956), the answer would seem clear-the concern has no right. However, the Heyer ruling recognized a right in a bidder to ". . have his bid honestly considered. The Government is under the obligation to honestly consider it and not to wantonly disregard it. If this obligation is breached and plaintiff is put to needless expense in preparing its bid, it is entitled to recover such expenses." To proceed from this to holding that award to a large firm which was obviously not eligible was violative of this principle would not seem too large a step for the court to take.

"Ct. Cl. Dec. No. 4I4-60, May Io, Ig63. 
The rule deducible from these decisions is that an award made under a total small business set-aside to a large business is not void $a b$ initio but is voidable at the election of the government.

Under a roo per cent or total set-aside, award is simply made to the small business concern submitting the lowest responsive bid. The partial set-aside procedure is considerably more complicated. As the term implies, in partial set-asides only a portion of the entire procurement is set aside for award to small business concerns. Thus, a procurement for which a partial set-aside has been made consists of two parts-the set-aside portion and the portion not set aside. Competition is, of course, unrestricted for the portion not set aside, so that both large and small business concerns may submit bids therefor. In order for a small business concern to be eligible for award of the set-aside portion, ${ }^{45}$ it must submit a responsive bid for the non-set-aside portion at a unit price within $r 20$ per cent of the highest award made on the non-set-aside portion. ${ }^{46}$ Then, negotiations are conducted giving priority to small business concerns which are also persistent or substantial labor surplus area concerns. Negotiations are conducted within each priority group commencing with the lowest responsive bid.

If a small business concern submits the lowest responsive bid on the non-set-aside portion it may, of course, receive the award thereof provided it is determined to be a responsible bidder by the contracting officer or is issued a certificate of competency by the Small Business Administration. In such case, the same concern also may be eligible to receive the award under the set-aside portion if there is no other eligible small business concern in a higher priority category willing to accept award of the set-aside portion at the price awarded for the non-set-aside portion.

Award on the set-aside portion shall be made at the highest price awarded on the non-set-aside portion. ${ }^{47}$ The validity of this requirement has been upheld by the Comptroller General ${ }^{48}$ and the contracting officer need not attempt to negotiate a lower price than that at which award was made on the non-set-aside portion. ${ }^{49} \mathrm{~A}$ small business concern which submits an "all or none" bid, signifying that its bid is conditioned upon receipt of both the non-set-aside portion and the set-aside portion submits a non-responsive bid, which cannot be considered for award of either portion. ${ }^{50}$

${ }^{40}$ ASPR I-706.6(c), 32 C.F.R. $\S$ I.706-6(c) (Supp. I963), and FPR I-I.706.6(c), 4I C.F.R. $\S$ I-1.706.6(c) (1963); Comp. Gen. Dec. No. B-r47682, Dec. 2r, r96r, 4r Decs. Comp. Gen. 4I7 (rg6r).

6 The purpose of these requirements is to limit participation for the set-aside portion to concerns which seriously compete for the non-set-aside portion. See Comp. Gen. Dec. No. B-147682, stupra note 45. Thus, where the bid of a small business concern for the non-set-aside portion was nonresponsive because of its failure to acknowledge receipt of an amendment to the invitation, it is not eligible for consideration under the set-aside portion.

${ }^{47}$ ASPR $1-706.6(\mathrm{c})$ and FPR I-1.706.6(c), supra note 45.

${ }^{48}$ Comp. Gen. Dec. No. B-I28955, Aug. 3I, I956, 36 Decs. Comp. Gen. I87 (1956), and id. Dec. No. B-r 47016 , Nov. I7, rg6r, 4 r Decs. CoMp. Gen. 306 (I96r).

${ }^{10}$ Id. Dec. No. B-150607, May 14, 1963 .

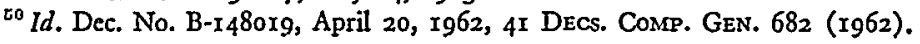


The Armed Services Procurement Regulation ${ }^{51}$ and the Federal Procurement Regulation $s^{52}$ provide that the non-set-aside portion of procurements involving a partial set-aside may be awarded by formal advertising or negotiation as appropriate and otherwise authorized. Regardless of the method of procurement utilized for the award of the non-set-aside portion of such procurements, award of the set-aside portion under the presently prescribed procedure clearly is effected by negotiation. The Comptroller General has said that this procedure constitutes negotiation since it involves material departures from the principles of formal advertising in that the bids of the small business concerns are not firm bids which may be accepted by the government; award of the set-aside portion ordinarily is made at a different amount than was bid; and the contract for the set-aside portion does not arise from acceptance by the government of an offer but from the acceptance by the small business concern of an offer by the government which the small business concern is not obligated to accept. ${ }^{53}$ He concluded "that Congress by enacting section fifteen of the Small Business Act has authorized the negotiation of partial set-asides for small business subsequent to the unrestricted formally advertised portion of a procurement."194

While the negotiated status of partial set-asides is accepted, SBA differs from the procuring agencies in its view of total set-asides. Paragraph I-706.8 of the Armed Services Procurement Regulation ${ }^{55}$ states that contracts for total set-asides entered into by conventional negotiation or by "Small Business Restricted Advertising" are negotiated procurements. However, under the "Small Business Restricted Advertising" method of procurement authorized for the award of roo per cent or total set-asides, bids submitted by small business concerns are binding upon the bidders and may not be withdrawn after bid opening. The low responsive bids may be forthwith accepted by the government and upon such acceptance a contract is created. This method, therefore, includes the essential features of the formal advertising method of procurement and, in the opinion of the SBA, constitutes "formal advertising."

The SBA has long contended that the formal advertising nature of a procurement is not destroyed because the bidding is restricted pursuant to statute to a limited class or group of bidders, namely, small business concerns. The Comptroller General in a decision dated October Io, I96r, has agreed with the SBA position, stating: ${ }^{.6}$

There is no requirement that small business contracts be awarded by formal advertising procedures, nor is there any provision in the act which would preclude small business awards through either formal advertising or negotiation procedures. Whether any particular method of contracting is to be considered as formal advertising or negotiation must

${ }^{51}$ ASPR x-706.5(b), 32 C.F.R. $\S x-706.5$ (b) (Supp. 1963).

${ }^{52}$ FPR I-706.5(b), 4 I C.F.R. \$ I-706.5(b) (I963).

${ }^{53}$ Comp. Gen. Dec. No. B-r 46677 , Oct. IO, I961, 4 I Decs. Conpr. Gen. 230 (1961).

E4 Id. Dec. No. B-I47or6, supra note 48.

${ }^{E 5} 32$ C.F.R. $\$$ I.706-8 (Supp. 1963). A similar provision is in the FPR $\S \mathrm{r}-\mathrm{x} .706 .8$, $4 \mathrm{I}$ C.P.R. $\S \mathrm{r}-\mathrm{r} .706-8(\mathrm{r} 963)$.

${ }^{60}$ Supra note 53, at 232. 
be determined on the basis of the actual terms of the procedure adopted, and not merely by the fact that it involves a small business set-aside.

III

\section{Certificates of Competency (COC)}

One of the most frustrating experiences a concern seeking a government contract can encounter is to discover that, although its bid or offer is fully responsive and low, it is denied the award because the contracting officer is of the opinion that the concern is "not responsible," that is, it lacks credit, facilities, experience, skills, know-how, or integrity, or it has a poor record of past performance. The courts and the Comptroller General have ruled consistently that the government is not obliged to award contracts to concerns which are "not responsible."57 Procurement regulations require the contracting officer to evaluate prospective contractors and if not satisfied with their experience, technical organization, reputation, financial resources and ability to refuse to award them the contract. ${ }^{58}$ In making this judgment the contracting officer has "a considerable range of discretion, and . . . the administrative determination will not be questioned unless arbitrary, capricious, or not based on substantial evidence."59 Thus, the test is not whether the contracting officer has exercised poor judgment, but whether he was derelict-a fact most difficult to establish where judgment is involved.

It is therefore surprising to many procurement officials and contractors to learn that when the contract is for more than $\$ 10,000$ and the low responsive bidder or offeror is a small concern, the contracting officer is not the final arbiter of many elements of responsibility and he must seek and accept SBA's determination as to these matters. Section $8(\mathrm{~b})(7)^{60}$ of the Small Business Act declares that:

It shall also be the duty of the [Small Business] Administration and it is hereby empowered, whenever it determines such action is necessary-...

(7) to certify to Government procurement officers ... with respect to the competency,

${ }^{67}$ Comp. Gen. Dec. No. B-120697, Aug. 20, 1954, 34 Decs. Comp. Gen. 86 (1954); id. Dec. No. B-132604, Dec. 23, 1957, 37 Decs. CoMp. Gen. 430 (1957); id. Dec. No. B-I35439, May 14, 1958, 37 Decs. CoMp. Gen. 756 (1958), and cases cited therein.

${ }^{58}$ ASPR I-903, 32 C.F.R. $\$$ r.903 (1961), and FPR I-I.310, 4I C.F.R. \$ I-I.310 (1963). These regulations are derived from 70A Stat. I30 (1956), Io U.S.C. $\$ 2305$ (c) (I958)and 63 Stat. 395 (I949), 4I U.S.C. $\$ 253$ (b) (1958), which provide for award to responsible bidders.

${ }^{50}$ Comp. Gen. Dec. No. B-151407, Sept. 25, 1963. The rule was summarized in id. Dec. No. B-151579, July 12, 1963, as follows: "In regard to the determination of the responsibility of a prospective contractor, the authorities are in agreement that the officers in whom the power is vested to determine 'responsibility' must determine the fact and such determination cannot be set aside unless the action was arbitrary, capricious, or fraudulent. Determination of the lowest responsible bidder is to be made by the authorized official of the contracting agency, who is required to act fairly upon reasonable information which supports the determination made. When such official determines the responsibility of a bidder, such determination cannot be overthrown by the courts or our Office unless it can be held that the determination was arbitrary, capricious, or fraudulent."

${ }^{10} 72$ Stat. 391, 15 U.S.C. $\$ 637$ (I958). This provision is a continuation of the authority originally vested in the chairman of the War Production Board by $\S 2(6)$, Pub. L. No. 603 , 77th Cong., $2 d$ Sess. (1942), approved July $\mathrm{Ir}, 1942,56$ Stat. 357. For a consideration of the legislative history of $\$ 8(\mathrm{~b})(7)$, sce Comp. Gen. Dec. No. B-139366, June 24, I959, 38 Decs, CoMp. Gen. 864 (1959). 
as to capacity and credit, of any small-business concern or group of such concerns to perform a specific Government contract. In any case in which a small-business concern or group of such concerns has been certified by or under the authority of the Administration to be a competent Government contractor with respect to capacity and credit as to a specific Government contract, the officers of the Government having procurement . . . powers are directed to accept such certification as conclusive, and are authorized to let such Government contracts to such concern or group of concerns without requiring it to meet any other requirement with respect to capacity and credit.

The statutes do not impose any limitation on SBA's authority. However, SBA in reliance on the discretion implicit in the statutory phrase, "whenever it determines such action is necessary," has agreed with the procuring agencies that its authority would not be exercised if the award is for less than \$10,000 or if the contracting officer, before rejecting the bid of the small concern, inserts in the contract file a written determination that the award must be made without the delay incident to requesting SBA to pass on the alleged lack of credit or capacity. ${ }^{01}$ This determination must be fully justified by the circumstances and SBA notified. ${ }^{62}$ The inclusion of these exceptions in the regulations issued by procuring agencies has given rise to the belief in some quarters that the exceptions existed by virtue of action of these agencies rather than action taken by the SBA, so that strict adherence to the terms of the exceptions is unnecessary. The Comptroller General, however, has recognized the exceptions as deviations from the applicable statutory provision requiring strict compliance; therefore, the failure to insert in the contract file a written determination before rejecting the small concern's bid is fatal. ${ }^{63}$ He also held that a non-referral to SBA cannot be justified if the urgency to make an award is caused by the contracting officer's delay after he becomes cognizant of the small concern's alleged lack of credit or capacity and if he then fails to ascertain whether the anticipated adverse consequence can be avoided by an interim contract action. ${ }^{64}$

From the outset, the word "credit" in section $8(\mathrm{~b})$ has been accepted by all as including every aspect of the bidder's financial status. However, the word "capacity" has been the subject of continued controversy. Procurement officials who view the Certificates of Competency (COC) as an unwarranted impingement on their authority and a separation of authority from responsibility seek to limit its scope. Small concerns mindful of past rejections of their bids or offers have endeavored to have the word given the widest possible import.

Initially many procuring officials held that capacity was confined to physical plant capacity. Under this restricted interpretation they were free to deny awards to small firms which in their opinion lacked "know-how," good management, or experience, or which had poor past performance records. While SBA did not

${ }^{61}$ ASPR I-705.6(b), 32 C.F.R. $\$$ I.705-6(b) (Supp. 1963), and FPR I-1.708-2(a), 41 C.F.R. \$I-I.708-2(a) (1963).

${ }^{22}$ Comp. Gen. Dec. No. B-151517, June 28, x963; id. Dec. No. B-15180r, Aug. 29, 1963; id. Dec. No. B-152716, Dec. 5, 1963 .

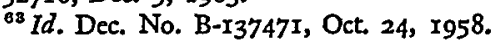

64 Id. Dec. No. B-15I801, supra note 62 . 
accede to this interpretation, it was not in a position to compel these procuring officials to modify their views. This situation continued until June 24, r959, when the Comptroller General, after reviewing the legislative history of section 8(b) (7), advised the Secretary of the Army that "capacity as used in section $8(b)$ (7) has reference to the over-all ability of a prospective small business contractor to meet quality, quantity, and time requirements of a procurement."

This landmark decision opened new horizons for small concerns. No longer was their capacity to perform completely subject to an almost unreviewable evaluation by an unfriendly contracting officer; now they could obtain an independent review from SBA. However, the application of this definition of "capacity" to specific cases has continued to present difficulties. While the contracting officer must seek SBA's determination of responsibility involving technical experience, knowledge, organization, skills, know-how, technical equipment and facilities, those elements of responsibility not demonstrative of ability to perform-even though they may affect the ultimate performance-are not subject to the COC procedure and remain in the exclusive domain of the contracting officer. These include integrity, perseverance, tenacity, qualification as a manufacturer or regular dealer, and debarment.

Poor past performance presents special difficulties. At first the Comptroller General viewed it as outside the scope of a COC. ${ }^{66}$ However, he soon recognized that the poor performance could have resulted from inadequate credit or capacity; and he has limited the early rulings to instances where inadequate credit or capacity is not the root of the poor performance. The burden of establishing that the COC

${ }^{\circ} I d$. Dec. No. B-r39366, supra note 6o. This decision was reaffirmed by a second letter to the Secretary of the Army in response to his request for reconsideration, of Nov. 6 , 1959. In reaching this conclusion, the Comptroller General first noted that " 'capacity' as used in section 8(b) (7) of Pub. L. No. $85-536$ is not defined therein nor is any light shed upon its intended meaning by the legislative history of that act. It is defined by standard dictionaries as 'legal qualification,' 'competency,' 'power, or fitness.' The term also has been defined as synonymous with 'ability." He then traced the development of section 8(b)(7) beginning with Pub. L. No. 603, 77th Cong., 2d Sess. (1942), 56 Stat. 351, to demonstrate the congressional intent that ability of the small concern was to be tested by the COC. Particularly significant was the statement of Congressman Patman that, "This group . . . will be able to investigate the credit standing and the ability to perform of any concern in the United States for a rating for that concern, and whatever this agency says about the credit standing and the ability to perform will be taken as conclusive by any agency of our government, and that is a very valuable feature, I must insist. Like it is now, when a procurement agency is anxious to let a contract of some kind for the manufacture of an essential war machine, what does the procurement officer do? Just like you would do or just like I would do. He gives it to a big concern like General Motors or General Electric, a concern about which there is no doubt as to its ability to perform or as to its credit rating. Then if there is some mistake made about that contract you cannot blame the procurement officer because he used good judgment, whereas if he had taken your concern in your district, which is just as good as any little concern in the world could possibly be, and whose credit rating is good and whose ability to perform is excellent, and then something happened, the procurement officer would be blamed. But, that is the object of this provision, and that is to place the responsibility in an agency to certify financial standing and ability to perform which shall be conclusive to that procurement offcer. Then if he gives it to the small concern, nobody can criticize him. He is not vulnerable, and I think that is an excellent provision." 97 Cong. Rec. 9154 (195I). For a comprehensive analysis of this decision, as well as a review of other pertinent decisions prior to the fall of $\mathbf{1 9 6 0}$, see Rumizen, Bidders' Responsibility and Certificates of Competency, 20 FED. B. J. 389 (rg60).

${ }^{\circ 6}$ Comp. Gen. Dec. No. B-135718, May 28, I958, 37 Decs. Comp. Gen. 798 (1958). 
is not applicable appears to be on the contracting officer, the Comptroller General having stated on September 25, I963, in Decision B-I5r407, that

... [at 38 Comp. Gen. 289] we made it clear that the ruling at 37 Comp. Gen. 798 (that a $\mathrm{COC}$ is not determinative of past poor performance) was intended to apply only in those instances where the contracting officer did not attribute the prior unsatisfactory contract performance to lack of capacity or credit. The contracting officer apparently concluded that a simple statement on his part was sufficient to bring the case within the rule at 37 CoMp. GEN. 798, so that the question of competency need not be submitted to the SBA. The decision at 38 CoMP. GEN. 289 was intended to justify a determination of nonresponsibility without reference to the Small Business Administration only when the record of poor past performance provided substantial evidence to demonstrate that such performance was due to one or more factors not included within capacity or credit. In this connection, we pointed out that 37 Comp. Gen. 798 should not be interpreted as justifying a conclusion that questions of capacity and credit and questions of past performance are necessarily unrelated.

Because the COC does not extend to situations where the bid or offer is nonresponsive-i.e., fails to conform to the essential requirements of the invitation for bids or request for proposals-contracting officers have declined to seek a COC even though the bid requirements were intended to elicit information as to the ability to perform and, thus, capacity. For example, small concerns were rejected because of a failure to meet experience requirements, or to submit appropriate descriptive data, or because of alleged failure of the pre-award sample to meet requirements. In a series of decisions, culminating in B-152027, issued on December 4, 1963 , the Comptroller General reaffirmed the rule that whatever the reason for rejection, if it is founded or predicated on the belief that the small concern is unable or unlikely to perform, the COC applies. ${ }^{6 \pi}$

Which of these causes are due to a bidder's lack of "capacity," as that term is used in section $8(\mathrm{~b})(7)$ of the Small Business Act? Failure due to the bidder's inability to do better clearly is. Failure because the bidder knowingly intended not to comply with specifications clearly is not. Unintentional failure because of carelessness or inadequate quality control in producing the samples seems to be fairly attributable to a shortcoming in "capacity." The remaining cause, failure fully to understand the specifications, may be due either to the bidder's carelessness in reading the specifications or his inability to understand their meaning. It seems to us that a bidder's ability or inability to understand specifications is part of his "capacity" to perform. Carelessness in reading the specifications, which might result, for example, in an assumption by the bidder that his standard commercial product conforms to the specifications, is not necessarily any indication of the bidder's ability, or even his willingness, to perform in accordance with the specifications. It may show a lack of capacity to prepare a bid properly, but we do not believe it demonstrates a lack of capacity to perform the contract.

\footnotetext{
${ }^{\text {67 }}$ Descriptive data relating to capacity, see id. Dec. No. B-r50373, March 7, x963; Dec. No. B-150704, April 24, 1963; cf. Dec. No. B-151807, July 24, I963; not relating to capacity, Dec. No. B-151901, July 17, 1963. For experience requirements relating to capacity, see id. Dec. No. B-146539, Aug. 10, 1961, 41 Decs. CoMp. GeN. I06 (I96I).
} 
After SBA issues a COC, may the contracting officer determine that the small business concern is not a responsible bidder for reasons not covered by the COC and reject the bid? The Comptroller General recently so held: "It is our position that while a bidder who has obtained a COC may be rejected, such rejection must be on the basis of nonresponsiveness, or if for nonresponsibility, on the basis only of some aspect not covered by the COC."

Because the applicable regulations ${ }^{69}$ clearly stated that a referral for a COC should be made only if the proposed rejection was for reasons of credit or capacity, SBA requested clarification of the decision, maintaining that if grounds existed for a determination of nonresponsibility based on factors outside the scope of a COC, they should be asserted prior to referral of the case to SBA. In a supplemental opinion on October 15, 1963, the Comptroller General stated:

We agree that, as a general proposition, the contracting officer should not be permitted to negate the authority of your agency under the $\mathrm{COC}$ procedure by the simple expedient of ascribing deficiencies in the record of performance of a bidder who has been issued a COC to factors not included within the scope of the certificate.

The Comptroller General held, however, that a contracting officer's determination, in connection with a referral to SBA, that the bid or proposal of a small business concern is acceptable except as to "capacity or credit" is not irrevocable! Not only did he rule that the COC could be so avoided in this manner, but he went further and stated: ". . . we question the advisability of making this kind of administrative determination irrevocable even if only by the contracting officer himself.... We do not agree ... that an attempt should be made to achieve (by regulation) the desired purpose by making irrevocable the contracting officer's determination to justify a submission under the COC procedure." Under this dictum, there is no way in which either SBA or the procuring agencies can effectively compel a contracting officer to perform his responsibility of determining whether a bid of a small concern is responsive to the invitation for bids (i.e., unqualifiedly offers to meet the terms of the invitation) and whether the bidder has the integrity required by regulations before turning to SBA for a COC. Thus, SBA and the bidder could be put to the unnecessary expense and labor of verifying capacity and credit of a bidder who is, in any event, ineligible for the award.

The procedure in processing a $\mathrm{COC}$ is for the contracting officer to notify the SBA Regional Office for his area of the proposed rejection for credit or capacity reasons of the bid or proposal of the small concern. Upon receipt of notice from a contracting officer that the bid or proposal of a small business concern is to be rejected for lack of capacity or credit, the SBA Regional Office contacts the small business concern and furnishes it instructions and rules for use in applying for a $\mathrm{COC}$. If the small business concern applies for a COC, an SBA Regional Office makes a

${ }^{88}$ Comp. Gen. Dec. No. B-15I121, Sept. 13, 1963.

${ }^{00}$ ASPR I-705.6(b) (iv), 32 C.F.R. § r.705-6(b) (4) (Supp. I963). 
survey of the financial capacity and productive facilities of the small business concern $^{70}$ If the applicant is determined to have the necessary capacity and credit to perform the proposed contract, SBA issues the COC. The issuance of a $\mathrm{COC}$ constitutes a reversal of the contracting officer's determination and the $\mathrm{COC}$ procedure is, therefore, in the nature of an appellate proceeding. If SBA does not find the concern can meet the time, quality, and quantity requirements, it will decline to issue the COC.

A COC is not a guaranty of performance by a small business concern and does not certify that such a concern will perform a government contract but only that it could perform. ${ }^{71}$ The Comptroller General has held in a line of decisions that the refusal of SBA to issue a COC is persuasive as to the competency of a small business concern and a denial constitutes an affirmation of the determination of nonresponsibility by the contracting officer. ${ }^{72}$ However, the refusal of a $\mathrm{COC}$ is not binding upon a contracting officer as to the responsibility of a bidder and the contracting officer has the final authority to determine whether the bidder is responsible to perform the contract. $^{73}$

The opinion has been voiced by some government contracting officers that SBA issues COC's automatically and arbitrarily. Such a misconception is best refuted by simply examining the record. From the inception of the program on August $\mathrm{r}$, 1953, through December 3I, I963, a total of 3,186 applications for COC's were filed. COC's were declined or applications were withdrawn in 1,732 cases and issued in I,437 cases. I,30I contracts valued at $\$ 256.8$ million resulted from these COC's and the estimated savings to the government (i.e., the difference in price of the small business applicant and the next highest bidder) in these cases amounted to \$2r.I million. Only fifty-three of the contracts resulting from these COC's or less than four per cent were defaulted.

Objective students of government procurement still find that too frequently government contracting personnel at the operational level resist dealing with small concerns when there is a large concern available to undertake the contract. In addition to the immediate damage to the small concern so rejected and the discouragement of small firms generally, there is loss to the government-in the form of a higher contract price, and a long-term loss in the form of lessened competition because of withdrawal of small concerns from government procurement. Even more important than these losses is destruction of the government's image for fairness and equal treatment. Alcaeus, in approximately 600 B.C., stated: "Not houses finely roofed or the stones of walls well-builded, nay nor canals and dockyards, make

${ }^{70}$ SBA Rules and Regulations 124.8-16(b), I3 C.F.R. $\$$ I24.8-16(b) (1958).

${ }^{71}$ United States v. Thompson, 168 F. Supp. 281 (N.D. W.Va. 1958), aff'd, 268 F.2d 426 (4th Cir. 1959); Comp. Gen. Dec. No. B-149937, Dec. 5, 1962.

${ }_{72}$ Comp. Gen. Dec. No. B-151834, Sept. 5, 1963; id. Dec. No. B-151848, Sept. 27, 1963; id. Dec. No. B-151977, Oct. 3, x963.

${ }_{73}$ Id. Dec. No. B-151897, Sept. 25, 1963. 
the city, but men able to use their opportunity." ${ }^{\text {"74 }}$ The $\mathrm{COC}$ was an attempt by Congress to insure that small firms, in dealing with the government, will not be deprived of their opportunity by the predilection of contracting personnel for dealing with large concerns. The congressional wisdom has been demonstrated by the program's success.

\section{Conclusion}

The government contracting agencies are aware of the complexity of government procurement procedures and the difficulties encountered by contractors in doing business with the government. Recommendations for improvement in contract award, negotiation and administration procedures are constantly being made by contractors, industry representatives, and trade associations. The contracting agencies are receptive to these suggestions and are making efforts to alleviate the difficulties of dealing with the government. A notable recent example was the announcement in January, I964, that the Department of Defense has commenced a project to incorporate all Defense procurement instructions into the Armed Services Procurement Regulation, thereby eliminating the need for the present separate procurement instructions of the military departments, the Defense Supply Agency, and their subordinate elements. ${ }^{75}$ This will obviously be of great and immediate benefit to all contractors dealing with the military, as it will enable them to ascertain more readily policy, procedure, and regulations governing the procurement of supplies and services for all military contracting agencies. Another example is in the field of patent policy-development of a policy as to whether the government or the contractor receives title to patent inventions which result from the performance of government contract. ${ }^{76}$ These and other improvements will inure to the benefit of small business concerns as well as large business.

Notwithstanding these efforts, there remains the need for vigilance by small concerns to be aware of the rights which are theirs exclusively and to assert such rights. The set-aside and Certificate of Competency programs constitute two such rights. If utilized, they are positive means of assistance in obtaining a fair proportion of government contracts.

The lawyer who fully understands and appreciates the implications of these programs can advise his small business client so that the latter can obtain maximum benefit from such programs and can thereby increase further small business participation in government procurement.

\footnotetext{
" Aristides, Rhodian Oration, I Lyra Grakca 339 (I922).

${ }^{75} \mathrm{CCH}$ Gov't Contracts Rep. No. 649 (Jan. 7, I964).

${ }^{70}$ For Statement of Government Patent Policy, see 28 Fed. Reg. Io943 (I963).
} 